\title{
Posibilități şi limite de tratament în deficitul primar selectiv de IgA - prezentare de caz
}

\author{
Monica Alexoae ${ }^{1}$, Mihaela Bataneant ${ }^{2}$, Ileana Ioniuc ${ }^{1}$, Alina Murgu', \\ Alice Azoicăi', Aurica Rugină'
}

\author{
${ }^{1}$ Clinica II Pediatrie, Universitatea de Medicină şi Farmacie „Gr. T. Popa“, Iaşi, România \\ ${ }^{2}$ Clinica III Pediatrie, Universitatea de Medicină şi Farmacie „Victor Babeş“, Timişoara, România
}

\begin{abstract}
REZUMAT
Deficitul primar de IgA este cea mai frecventă imunodeficiență congenitală definită de valori ale IgA serice sub $0,07 \mathrm{~g} / \mathrm{l}$ şi valori normale ale IgG şi IgM. Marea majoritate a cazurilor sunt asimptomatice, doar $10-15 \%$ se manifestă prin infecții sinopulmonare persistente sau recidivante, boli autoimune, alergii, malignități. Unele cazuri dezvoltă în timp imunodeficiență comună variabilă. Apariția anticorpilor anti-lgA justifică administrarea cu prudență a transfuziilor de sânge, plasmă sau imunoglobuline intravenoase. Autorii prezintă un caz de deficit primar selectiv de IgA la care severitatea exacerbărilor infecțioase pare a fi determinată de asocierea unui deficit de IgG4 şi discută posibilitățile şi limitele terapiei în lumina datelor recente din literatură.
\end{abstract}

Cuvinte cheie: deficit primar de IgA, subclase IgG

Imunodeficiențele primare reprezintă boli genetice rare a căror prevalență nu este cunoscută cu exactitate. Conform Societăţii Europene de Imunodeficiențe (ESID), cele mai frecvente sunt imunodeficiențele prin anticorpi-56,1\% (imunodeficiența comună variabilă, deficitul primar selectiv de IgA, deficitul de subclase de IgG), urmate de defectele fagocitelor $(11,2 \%)$, deficite imune celulare $\mathrm{T}$ şi B $(8,4 \%)$, boli genetice ale reglării imune $(2,7 \%)$, deficite ale sistemului complement $(2,5 \%)$, boli autoinflamatorii $(0,4 \%)$, defecte la nivel de receptori şi componente de semnalizare $(0,4 \%)(1)$.

Deficitul primar selectiv de IgA este cea mai frecventă imunodeficiență primară la populația caucaziană. Incidența bolii, subestimată deoarece nu există programe de screening, este diferită în relație cu etnia (1:143 persoane în Peninsula Arabă, 1:875 în Marea Britanie, 1:14.800-18.500 în Japonia) (2). Marea majoritate a cazurilor (85-90\%) sunt asimptomatice, $10-15 \%$ se manifestă prin infecții sinopulmonare recurente, infecții/tulburări gastrointestinale, afecțiuni alergice, boli autoimune sau malignități.

\section{PREZENTAREA CAZULUI}

JI, sex masculin, 8 ani, mediul rural, internat pentru prima dată în Clinica II Pediatrie la vârsta de 6 ani, ulterior prezentându-se pentruu reevaluare periodică sau cu ocazia exacerbărilor.

Antecedente heredo-familiale - nesemnificative. Antecedente personale fiziologice: al doilea copil al cuplului, născut natural la vărsta gestaţională de 38 de săptămâni cu greutatea de 3.300 grame şi talia de 51 centimetri; a efectuat vaccinările din schema națională şi, în plus, vaccinare antipneumococică şi antirotavirus. Antecedente personale patologice - nesemnificative până la vârsta de doi ani, apoi episoade recidivante de angină pultacee febrilă tratate cu antibioterapie timp de 7-10 zile cu recurență la aproximativ trei zile de la oprirea tratamentului; adenoamigdalectomie (3 ani); rinosinuzite şi pneumopatii recidivante.

La vârsta de 6 ani este internat în Clinica II Pediatrie a Spitalului Clinic de Urgențe pentru Copii „Sf. Maria“, Iaşi, prezentând stare generală influențată, normal dezvoltat staturoponderal, paloare 
cutaneo-mucoasă, malpoziţii şi distrofii dentare, asimetrie toracică (Fig. 1), pectus excavatum, adenopatie axilară dreaptă de aproximativ un centimetru, nev pigmentar subscapular drept, trei formațiuni tumorale, de consistență fermă, cu diametrul maxim de $1,5 \mathrm{~cm}$, mobile pe planurile adiacente, situate scapular drept, hiperlaxitate ligamentară (Fig. 2), cutis elastica (Fig. 3), obstrucție nazală, rinoree muco-purulentă, tuse productivă predominant matinală, raluri subcrepitante şi intermitent sibilante diseminate pe ambele arii toracice.

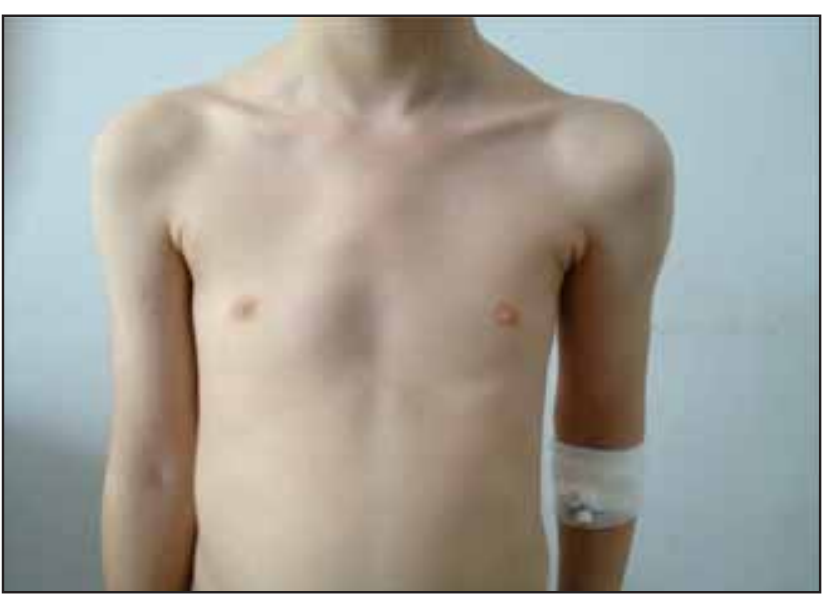

FIGURA 1. Asimetria cutiei toracice

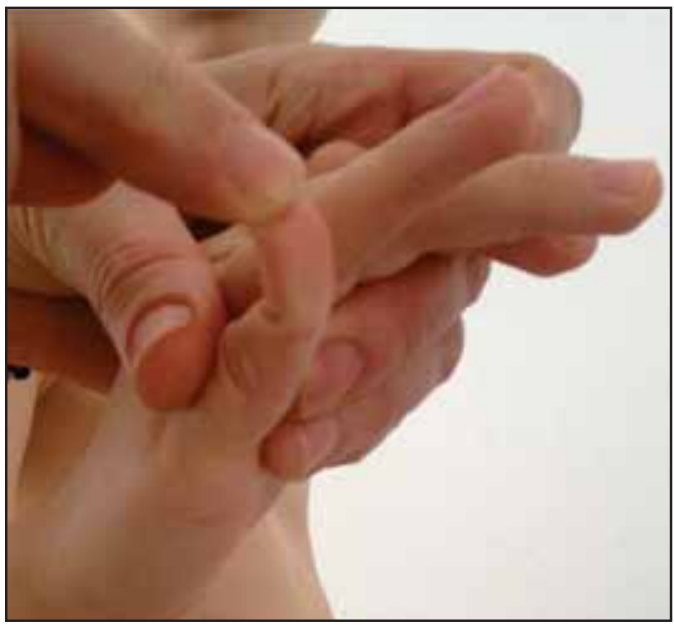

FIGURA 2. Hiperlaxitate ligamentară

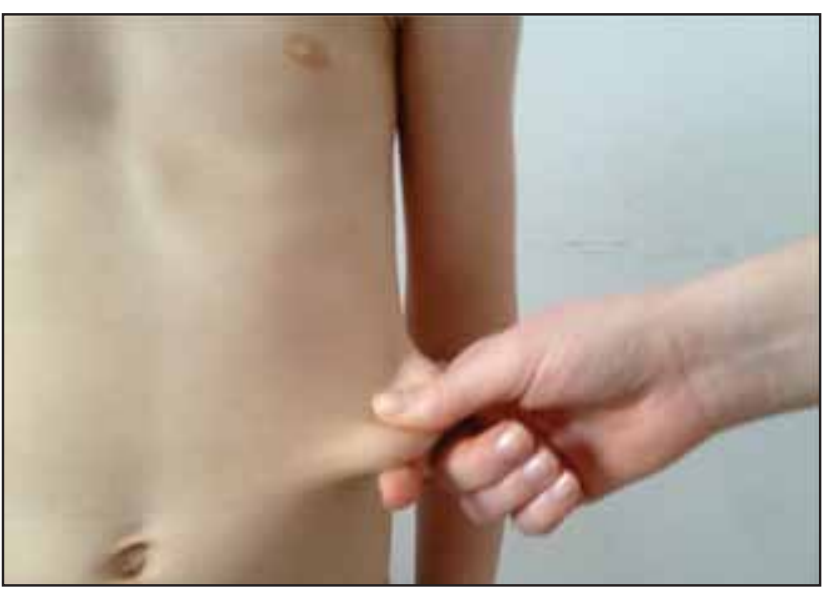

FIGURA 3. Hiperelasicitate cutanată
Explorarea infecțiilor recidivante a presupus derularea eşalonată a unui protocol complex de investigații biologice, imunologice şi paraclinice în Spitalul de Copii „Sf. Maria“, Iaşi şi Spitalul de Copii „Luis Țurcanu“, Timişoara.

Hemoleucograma şi reactanţii de fază acută au avut valori normale.

Electroforeza proteinelor serice a fost normală; imunograma serică a obiectivat valori scăzute (sub $0,05 \mathrm{~g} / \mathrm{l})$ ale IgA serice cu titru IgG şi IgM normal pentru vârstă, dar cu nivele scăzute ale subclasei $\mathrm{IgG}_{4}$. Analiza subpopulațiilor limfocitare a documentat scăderea limfocitelor $\mathrm{T} \mathrm{CD}_{8}$ şi creşterea raportului $\mathrm{CD}_{4} / \mathrm{CD}_{8}$ (Tabelul 1). Dozarea anticorpilor antitetanos a evidențiat titru protector.

TABELUL 1. Investigații imunologice

\begin{tabular}{|l|c|}
\hline Imunogramă & \\
Ig A (VN:0,53-2,04) g/I & $<0,05$ \\
Ig G (6,98-15,6) & 14,88 \\
Ig M(0,31-1,79) & 1,56 \\
\hline Subclase IgG 1 (3,5-9,1 g/I) & 11 \\
gG 2 (0,85-3,3 g/I) & 1,3 \\
IgG 3 (0,20-1,04 g/I) & 0,83 \\
IgG 4 (0,030-1,577 g/l) & 0,02 \\
\hline Subpopulatii limfocitare & \\
Limfocite (2.000-2.700/mmc) & 2194 \\
Limfocite B (300-500/mmc) & 386 \\
Limfocite T (1.400-2.000/mmc) & 1152 \\
CD4+ ( 700-1.100/mmc) & 660 \\
CD8+ (600-900/mmc) & 335 \\
NK (200-300/mmc) & 601 \\
CD4/CD8 (1,1-1,4) & 1,97 \\
\hline
\end{tabular}

Examinarea CT toracică a confirmat anomalia de conformație cu asimetria cutiei toracice şi a evidenţiat un focar de condensare bazal lateral stâng, bronşiectazii nesistematizate, unele cu contur aeric altele cu impactare mucoidă (Fig. 5, 6), formațiuni de țesut moale, iodofile, omogene, subcutanate, la nivelul peretelui posterior al hemitoracelui drept.

Paleta investigațiilor a fost extinsă ținând seama de complexitatea tabloului clinic:

- asocierea bronşiectaziiilor evidențiate la examinarea CT a impus efectuarea iontoforezei care a obiectivat valori normale ale $\mathrm{NaCl}$ (12 $\mathrm{mmmol} / \mathrm{l})$.

- explorarea adenopatiilor superficiale şi profunde a presupus excluderea serologică a infecțiilor cu Toxoplasma, Brucella, citomegalovirus, $\mathrm{HIV}_{1,2}$, Bartonella Henselae (anticorpi de tip IgG şi IgM - negativi); s-a confirmat infecția acută cu virus Epstein Barr prin pozitivitatea anticorpilor de tip IgM anti-VCA şi anti-EBNA.

- explorări privind riscul infecțiilor şi inflamațiilor care însoțeşte deficitul seric al IgA 


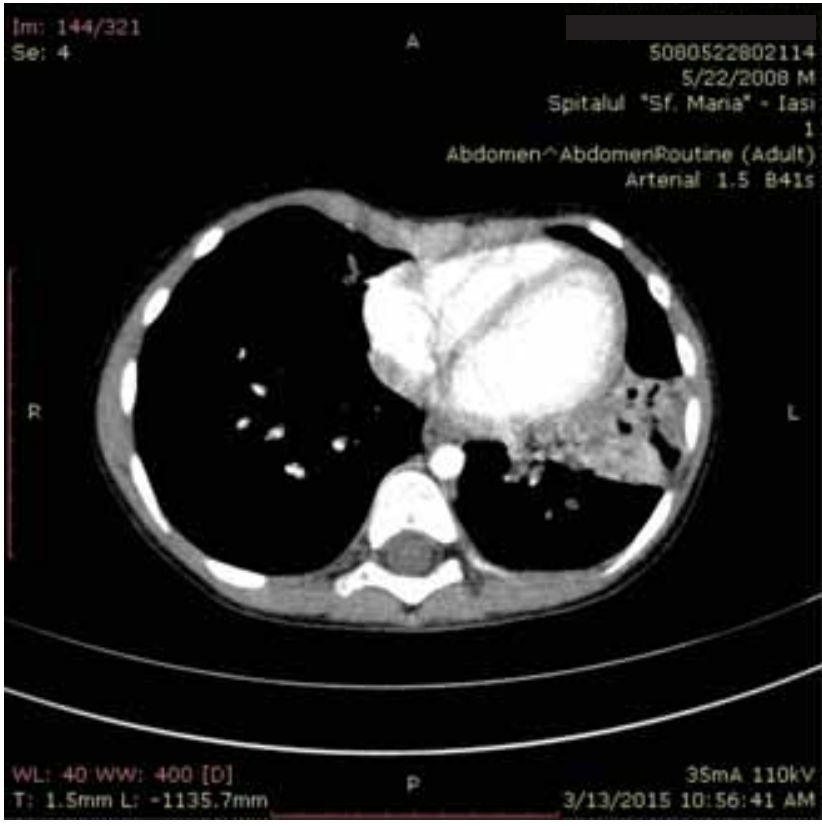

FIGURILE 5, 6. Bronşiectazii nesistematizate bilaterale

asociat cu cel al IgG4: culturi din exudatul nazal, faringian, spută, materii fecale, antigen fecal al H.Pylori şi calprotectina fecală. Rezultatele acestor investigații au fost negative.

În urma derulării investigațiilor, diagnosticul pozitiv al cazului a fost:

- Deficit primar selectiv de IgA cu deficit de IgG4;

- Pneumonie bazală stânga;

- Bronşiectazii nesistematizate bazale bilaterale;

- Observație sindrom Ehlers-Danlos (observație susținută şi de specialistul genetician);

- Infecție acută cu virus Epstein-Barr.

Tratamentul antibiotic, antiviral, simptomatic, a fost urmat de excizia chirurgicală a formațiunii subcutanate situate infrascapular drept; aspectul histopatologic a sugerat o hiperplazie foliculară reactivă nespecifică.

Evoluția clinică a fost favorabilă. La externare a fost elaborată o schemă de dispensarizare specială, au fost informați şi consiliați părinții ținând seama de riscurile imunodeficienței umorale.

\section{DISCUȚII}

Deficitul selectiv de IgA, cea mai frecventă imunodeficiență primară umorală, se caracterizează prin valori nedetectabile (sub $7 \mathrm{mg} / \mathrm{dl}$ ) ale concentraţiilor serice de IgA în prezența unui titru normal al IgG şi IgM. Diagnosticul se precizează cu certitudine la copilul cu vârsta peste 4 ani după excluderea altor cauze de hipogamaglobulinemie, cel mai frec-

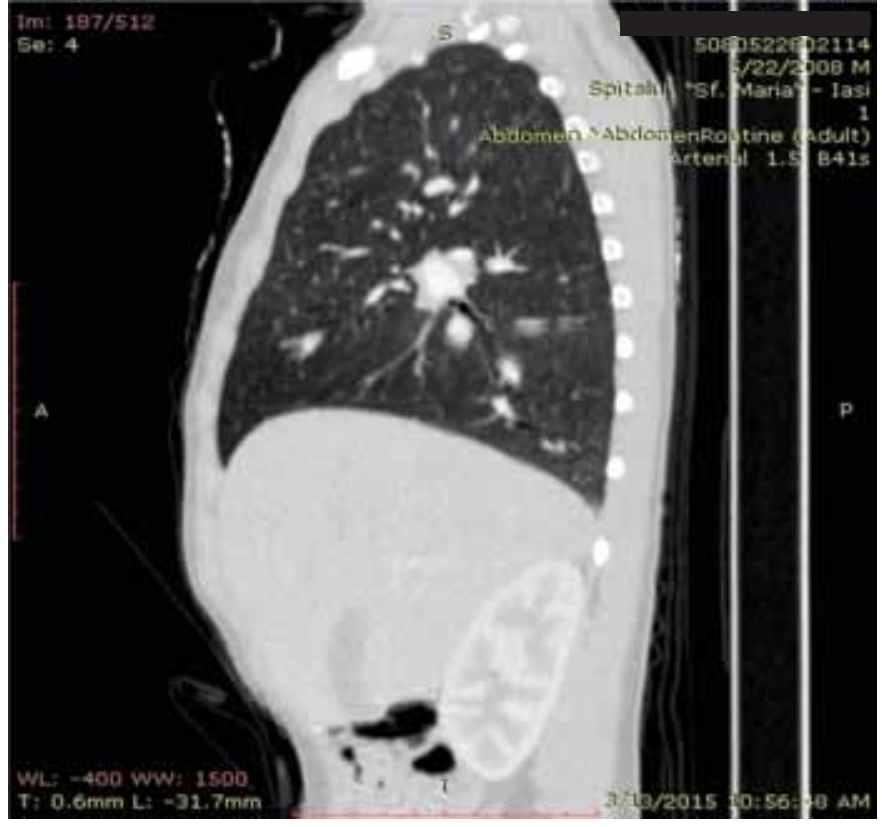

vent tranzitorii: infecţioase (infecția HIV, mononucleoza infecțioasă, infecția congenitală cu citomegalovirus, Toxoplasma gondii sau virusul rubeolic), medicamentoase, malignități, afecțiuni sistemice asociate cu pierderi excesive ale imunoglobulinelor (sindrom nefrotic, arsuri întinse, limfangiectazie intestinală) (3).

Boala este asimptomatică în $85-90 \%$ dintre cazuri, fiind diagnosticată fortuit, cel mai frecvent printre persoanele donatoare de sânge şi doar în 10$15 \%$ se manifestă prin infecții sinopulmonare recidivante. Susceptibilitatea la infecții nu se corelează, în cele mai multe studii din literatură, cu severitatea deficitului de IgA, ci cu prezența concomitentă a deficitului de $\operatorname{IgG}_{4}$ şi/sau $\operatorname{IgG}_{2}$ şi cu răspunsul inadecvat la vaccinarea antipneumococică şi anti-Haemophilus tip B (4). Alte condiții imunologice asociate cu deficitul primar de IgA sunt imunodeficiența comună variabilă, sindromul hiperIgM, sindromul ataxie-telangiectazie, deleția $18 \mathrm{q}$ sau 22q11.2, candidiaza cutaneo-mucoasă, deficitele de complement, deficitul de IgE.

La cazul prezentat, surprinderea în evoluție a unei limfopenii CD8 necesită monitorizare pentru surprinderea unei eventuale imunodeficiențe complexe combinate.

Pacienții cu deficit primar de $\operatorname{IgA}$ au un risc crescut de boli autoimune, în special lupus eritematos sistemic (1-5\% cazuri), artrită reumatoidă (2$4 \%$ cazuri), boală celiacă, diabet zaharat insulinodependent, miastenie gravis, tiroidită autoimună. Chiar în absența simptomelor clinice, prevalența autoanticorpilor (factor reumatoid, anticorpi anti- 
cardiolipină, anticorpi antinucleari) este mai mare decât în populația generală (5).

$\mathrm{Nu}$ există terapie specifică pentru această imunodeficiență primară. Se acceptă antibioterapia profilactică la copiii cu infecții recidivante administrată continuu sau doar în anotimpul rece cu riscul suprainfecției cu fungi şi dezvoltării rezistenței bacteriene.

Clasic, deficitul primar de IgA era considerat principala contraindicaţie a administrării de imunoglobuline intravenoase din cauza apariţiei anticorpilor anti-IgA, riscul reacțiilor sistemice severe fiind mai mare în condițiile asocierii deficitului de $\operatorname{IgG}_{2}(3)$. Autoanticorpii anti-IgA sunt cel mai frecvent de tip IgG1, sunt prezenți în proporție de 9-44\% la pacienții cu deficit primar de IgA şi pot reprezenta cauza reacțiilor severe declanşate de transfuzii de sânge, plasmă, imunglobuline intravenoase. Riscul de apariție al adevăratelor reacții anafilactice depinde de prezența şi concentraţia anticorpilor anti-IgA de tip IgE, a căror prevalență este mult mai mică (6), specificitatea acestora, cantitatea de IgA în produsul administrat, calea de administrare (7).
Studii recente demonstrează siguranță în administrarea intravenoasă sau subcutanată a produselor cu conţinut scăzut de $\operatorname{IgA}$ (sub $0,5 \mathrm{mg} / 1$ ) la copiii cu deficit concomitent de $\mathrm{IgG}_{4}$. Incidența reacțiilor adverse sistemice severe (dispnee, febră, dureri abdominale intense, mialgii, hipotensiune arterială) înregistrate pe un lot de cinci copii urmăriți prospectiv care au primit 170 perfuzii intravenoase cu imunoglobuline a fost de 5,3\% fără a se înregistra reacții anafilactice (8). Eficiența acestor preparate analizată prin prisma scăderii frecvenței exacerbărilor infecțioase este controversată, astfel încât majoritatea autorilor recomandă terapie lunară timp de 6 luni, apoi evaluare şi întrerupere în absența ameliorării.

În concluzie, terapia copilului cu deficit de IgA simptomatic presupune tratarea promptă a infecțiilor, eventual antibioterapie profilactic.

Cazul prezentat este particular prin prezența elementelor clinice: cutis laxa, hiperlaxitatea ligamentară şi asimetria toracică, nivelele scăzute ale $\mathrm{IgG}_{4}$ şi asocierea limfocitopeniei CD8, impunând o atentă supraveghere pe termen lung. 